\title{
WHAT DETERMINES THE AMBITIOUSNESS OF CLIMATE POLICY IN DIFFERENT COUNTRIES? ${ }^{1}$
}

\author{
I. Stepanov, N. Agikyan, E. Muzychenko
}

Ilia Stepanov, Deputy Head, Laboratory for Economics of Climate Change, National Research University Higher School of Economics, Malaya Ordynka 17 St., Moscow, 119017, iastepanov@hse.ru

Natella Agikyan, Research Assistant, Laboratory for Economics of Climate Change, National Research University Higher School of Economics, Malaya Ordynka 17 St., Moscow, 119017, nagikyan@hse.ru

Evgeniya Muzychenko, Research Assistant, Laboratory for Economics of Climate Change, National Research University Higher School of Economics, Malaya Ordynka 17 St., Moscow, 119017, emuzychenko@hse.ru

\section{Abstract}

Climate change is considered to be the one of the most challenging problems of the 21 st century and requires coordinated action by the governments across the globe. The Paris Agreement, ratified by most countries of the world, sets the goal of keeping the average temperature rise within $2^{\circ} \mathrm{C}$ compared to pre-industrial levels. As part of the Agreement, countries set Nationally Determined Contributions (NDCs) - targets for reducing greenhouse gas emissions, determined voluntarily. Because these targets are nationally determined, they depend on domestic constraints and the additional opportunities that individual countries' emission reduction strategies present.

As a result, climate policies vary widely among countries, both in terms of the emission reduction targets and the policy instruments used. This study aims to systematize the factors influencing climate policy and relies on factor and cluster analysis methods. Factor analysis is used to aggregate a set of investigated statistical indicators, reflecting the country's development level, exposure to climate risks, energy endowment, and foreign trade specialization, into a series of principal components. Based on the selected principal

\footnotetext{
1 The article was submitted 25.10.2021.
} 
components, the countries are clustered into homogeneous groups and the indicators of climate policy ambitiousness is compared among the clusters.

The results of the study demonstrate that climate change vulnerability is not a determinant of climate policy. As a rule, the poorest and most vulnerable countries set the least ambitious emission reduction targets. At the same time, rich and energy-abundant countries are more likely to implement active climate policies and set more ambitious emissions reduction targets, compared to energy-intensive countries and countries that specialize in exporting carbon-intensive products. More advanced climate policy instruments, such as a carbon tax or emissions trading system, are used more frequently in more advanced and energy-deficient countries.

Key words: climate change, climate policy, GHG emissions reductions, Paris Agreement, nationally determined contributions (NDCs), economic development, energy dependency.

For citation: Stepanov I, Agikyan N., Muzychenko E. (2021) What Determines the Ambitiousness of Climate Policy in Different Countries. International Organisations Research Journal. Vol. 17, No. 4, pp. doi: https: //doi.org./10.17323/1996-7845-2021-0403

\section{Introduction}

The global climate change is recognized as one of the most challenging issues of the 21 st century, requiring joint action by national governments. The Paris Agreement, which came into force in 2016 and has been ratified by 193 countries worldwide, sets the goal of keeping average temperatures within $2^{\circ} \mathrm{C}$ of pre-industrial levels. Under this framework, countries set Nationally Determined Contributions (NDCs) - targets for reducing greenhouse gas (GHG) emissions, determined voluntarily ${ }^{2}$.

Since the setting of these goals is national in scope, it depends both on domestic constraints and on the additional opportunities that individual countries' emission reduction strategies offer. As a result, goals vary widely in their ambitiousness, as do climate policy measures: some countries limit themselves to administrative measures to control emissions (efficiency standards and regulations, mandating the use of specific technologies, etc.), while others use more advanced instruments, such as a carbon price (in the form of a carbon tax or emissions trading system).

\footnotetext{
${ }^{2}$ Climate change is a long-term statistically significant change in climate variables, such as surface temperature and precipitation. Climate change is also manifested in the growing "nervousness" of the climate - an increase in temperature amplitudes and an increase in weather anomalies, such as droughts, extreme precipitation, gusty winds, etc.
} 
In the academic literature, there is a great amount of evidence that the ambitiousness of climate policy is determined by a combination of climatic and socio-economic factors [1], [2], [3], [4], [5], [6]. The willingness of a country to adopt strict targets to reduce or limit emissions growth depends not only on objective factors of exposure to climate change, but also on the level of its economic development, fossil fuel endowment, energy and technological policy objectives, and other socio-economic factors. With few exceptions, in general, the literature on the influence of such factors is not systematic and is limited to the research of specific countries or particular factors [5], [6].

The purpose of this study is to classify the factors determining climate policy by clustering countries according to the influence of different groups of factors. The study is based on the methods of factor and cluster analysis. Factor analysis is used to aggregate the set of statistical indicators under review, reflecting the country's level of development, vulnerability to climate change, energy supply, and foreign trade specialization, into a series of principal components. Based on the selected principal components, countries are clustered into homogeneous groups and indicators of climate policy ambitiousness are compared between the clusters.

The study demonstrates that the exposure to climate change is not a key determinant of climate policy. As a rule, the poorest and most vulnerable countries set the least ambitious emission reduction targets. At the same time, rich and energy-deficient countries are more likely to set aggressive climate policies and more ambitious emissions reduction targets, compared to energy-abundant countries and countries that specialize in exporting carbonintensive products. More advanced climate policy instruments, such as a carbon tax or emissions trading system, are used more frequently as climate policy instruments in more advanced and energy-deficient countries.

The paper consists of four sections. The first one considers the main factors influencing climate policy and national GHG emission reduction targets. The second part defines and formalizes the concept of climate ambitiousness through a description of various approaches to its quantitative measurement. The third section describes the methodology of the study, and the fourth presents its results. Finally, the fourth section formulates the main conclusions, including the importance of redefining current international approaches to national climate responsibility.

\section{Factors determining climate policy}


Climate change has a direct impact on the lives and economies of countries around the world. Several studies demonstrate that developing countries dependent on agriculture are especially vulnerable to climate change [7], [8], [9]. The effects of climate change tend to worsen over time, which poses an additional threat to the poor agrarian-oriented countries (mostly African and Asian).

Climate change poses a particular threat to small island states, which may face the risk of flooding as a result of rising ocean levels [9]. These countries traditionally play an important role in the international negotiation process on the climate problem [10]. Many of them perceive climate change not just as a long-term risk, but as a direct threat to their existence in a few years [11].

The climate change vulnerability can be considered as one of the factors shaping countries' attitudes to the demand for urgent emission reduction measures, and thus influencing the ambitiousness of their climate policy [12], [5]. On the other hand, the mission of industrialization and economic growth can be the factor limiting the possibilities of implementation of an active policy for emissions reduction.

Development goals, especially in developing countries, often conflict with emission reduction goals because solving fundamental social problems is more urgent for these countries, but it seems impossible without affordable and low-cost fossil fuel energy [13]. The level of socio-economic development largely determines the ability, and therefore the willingness of the country to support measures to combat climate change [14]. For developing countries, the task of adapting to climate change through accelerated development often presents a more attractive alternative to costly measures of emissions reduction [15], [16].

The mutual exclusivity between the objectives of environmental policy and growth is well illustrated by the theoretical concept of the environmental Kuznets curve [17], [18], [19], according to which, in the initial stages of economic development, the increase in production capacity leads to an increase in GHG emissions. After passing the phase of active industrialization there are changes in the industrial structure (growth in the share of the services in GDP) and in the overall efficiency of production processes (through development of cleaner and less resource-intensive production technologies). The tendency to transfer some industrial capacities to developing countries that are more attractive for production is increasing [20], which leads to a decrease in emissions compared to previous periods [21]. Nowadays, most countries of the world are still far from the trajectory of GHG emissions 
reduction [22], [23]. Most empirical estimates of the Kuznets curve for GHG emissions indicate that for most countries the breaking point is hardly achievable over a horizon of several decades [24], [25].

Nevertheless, a high level of welfare can serve as a prerequisite for a relatively more active environmental and climate policy, both because of the relatively greater financial capacity of developed countries compared to developing countries, and because of the presence of several indirect factors which play out especially in wealthy countries. These include the quality of political institutions, which are more responsive to social demand for environmental issues [26], [5].

However, several works indicate that vulnerability to climate change and the level of economic development is far from being the only factors influencing climate policy and emission reduction targets [5], [6]. Especially in developed countries, policies to reduce emissions have long been closely correlated with energy policy objectives.

The EU policies to improve energy security and industrial competitiveness are simultaneously aimed at realizing the potential of renewable energy and reducing GHG emissions. By 2030, the EU plans to reduce emissions by at least 55\% from the 1990 level, increase the share of renewables in total energy consumption to $32 \%$ and increase energy efficiency by $32.5 \%$ [27], by 2050 the goal is to achieve carbon neutrality. In the European context, the policy of reducing emissions to a large extent underlie policies aimed at strengthening the positions of national producers of renewable energy and reduction of the Union's dependence on the fossil fuels imports.

Schmitz [1] explains China's climate policy through the perspective of its energy policy. In the case of China, the country's rapidly growing demand for energy has forced it to import large quantities of energy, which poses the problem of energy dependence.

In addition to the influence of energy policy on emission reduction goals, several studies note that other country-specific factors influence countries' climate policy [1], [28], [4]. For example, the development of renewable energy in China solves the problem of air pollution, as well as significantly stimulates small businesses. The development of this industry not only contributes to economic growth, but also creates jobs and increases the income level of the population [1].

Finally, countries' specialization in fossil fuel extraction and export [5], [6] can influence emission reduction policies. First, countries with large fossil fuel reserves as a source of government and corporate revenues tend to find it more difficult to implement an 
active climate policy. Second, in countries with large fossil fuel reserves, the implementation of climate policy measures is often obstructed by large fossil fuel lobby groups. For example, Levy and Egan [29] demonstrate the way a coalition of the fossil fuel industry successfully prevented the US from adopting ambitious targets under the Kyoto Protocol.

Policies to reduce GHG emissions are not just about combating global climate change; they have become a tool for addressing a range of development challenges, from enhancing the competitiveness of individual industries to addressing energy security issues. Willingness to set ambitious emission reduction targets depends on several socio-economic development factors. Analysis of these factors is presented in the following paragraphs.

\section{The comparison of the ambitiousness of climate policies: existing approaches}

In this paper, the ambitiousness of climate policy implies both the country's willingness to commit to reducing GHG emissions and the desire to pursue an active climate policy. We suppose that the more these commitments are, the higher the ambitiousness of climate policy is.

One of the possible criteria for assessing the ambitiousness of climate policy can be nationally determined contributions (NDC) to the reduction of GHG emissions, formulated within the framework of the Paris Agreement. The use of this indicator is suitable because it allows us to include a significant number of countries - 194 countries have already submitted their first NDCs. On the other hand, comparison of NDCs between countries is difficult for several reasons.

Firstly, different countries use different base years (for example, 1990, 2005 and 2010), relative to which the emission reduction target is calculated, as well as different target years $(2025,2030,2035)$, by which they plan to achieve this reduction.

Secondly, there are several approaches to formulate NDCs: some countries set goals to reduce the absolute amount of GHG emissions directly whereas others formulate them in terms of the carbon intensity of GDP indicating relative goals - an expected reduction in GHG emissions per unit of output. Finally, another approach to determine NDC is to set emission reduction targets relative to the BAU (Business as usual) scenario, which is used by countries such as Indonesia and Mexico (Table 1).

To overcome these barriers and compare the NDC between countries, the years of 2016 and 2030 were chosen as the base and target year, respectively. For some countries, 
relative emission reduction targets have been converted to absolute and vice versa ${ }^{3}$. The carbon intensity of GDP was calculated as the ratio of the absolute volume of GHG emissions (according to the stated goals) to the projected GDP in 2030. Absolute emissions in 2016 and 2030, as well as the changes in the carbon intensity of GDP by 2030, were used to recalculate the goals formulated with respect to BAU.

Table 1. Examples of conversion of NDC in given countries into the compatible indicator of ambitiousness of climate policy

\begin{tabular}{|l|c|c|c|c|c|c|}
\hline $\begin{array}{c}\text { Nountry / } \\
\text { base year } \\
\text { NDC } \\
\text { reduction by } \\
\text { the target } \\
\text { year (2030) } \\
\text { compared to } \\
\text { the base } \\
\text { year, \% }\end{array}$ & Target type & $\begin{array}{c}\text { Emissions } \\
\text { in the base } \\
\text { year, } \\
\text { million } \\
\text { tons of } \\
\text { CO2-eq. }\end{array}$ & $\begin{array}{c}\text { Emissions } \\
\text { in 2016, } \\
\text { million } \\
\text { tons of } \\
\text { CO2-eq. }\end{array}$ & $\begin{array}{c}\text { Compatible } \\
\text { target: } \\
\text { absolute } \\
\text { change by } \\
\text { 2030 } \\
\text { compared } \\
\text { to 2016, \% }\end{array}$ & $\begin{array}{c}\text { target: } \\
\text { change in } \\
\text { the carbon } \\
\text { intensity of } \\
\text { GDP by } \\
\text { 2030 } \\
\text { compared } \\
\text { to 2016, \% }\end{array}$ \\
\hline $\begin{array}{l}\text { Brazil / } \\
2005\end{array}$ & $-43 \%$ & Absolute & 2015,5 & 1379,4 & $-17 \%$ & $-42 \%$ \\
\hline $\begin{array}{l}\text { Chile / } \\
2010\end{array}$ & $-26 \%$ & Relative & 70,2 & 87,9 & $-41 \%$ & $-13 \%$ \\
\hline $\begin{array}{l}\text { Mexico / } \\
2013\end{array}$ & $-25 \%$ & BAU & 0 & 688,4 & $+10 \%$ & $-24 \%$ \\
\hline $\begin{array}{l}\text { Denmark / } \\
2010\end{array}$ & $-41 \%$ & Absolute & 62,2 & 46,7 & $-21 \%$ & $-39 \%$ \\
\hline $\begin{array}{l}\text { Malta / } \\
2010\end{array}$ & $-35 \%$ & Absolute & 3,0 & 1,9 & $+2 \%$ & - \\
\hline $\begin{array}{l}\text { India / } \\
2005\end{array}$ & $-33-35 \%$ & Relative & 1803,3 & 3235,7 & $-64 \%$ & $-9 \%$ \\
\hline $\begin{array}{l}\text { China / } \\
2005\end{array}$ & $-60 \%$ & Relative & 9280,0 & 11576,9 & $-20 \%$ & $-49 \%$ \\
\hline
\end{tabular}

Source: compiled by authors based on Climatewatch

In addition to assessing the ambitiousness through NDCs, this work takes into account the estimates by the Climate Action Network (CAN), the leading European coalition of public organizations fighting climate change. The objective of their assessment is to characterize the efforts of countries aimed at combating climate change, as well as the results of the climate policy in European countries. The methodology for measuring CAN indicator is based on five main components:

1. The degree of achievement of the goals set by the countries by 2020 for the development of renewable energy, energy saving technologies and emissions;

\footnotetext{
${ }^{3}$ The transition from absolute emission reduction goals formulated in the NDC of most parties to the Paris Agreement to relative ones is due to the need to mitigate the problem of the difference in the ambitiousness of climate policy in countries with different levels of economic development. In other words, a 10\% reduction in absolute emissions in a developing country is a much less ambitious goal compared to a $10 \%$ reduction in emissions in a developed country, where the potential for cheap emission reductions has already been largely exhausted. The transition to relative emission reduction targets partially solves this problem.
} 
2. A number of climate and energy indicators (GHG emissions per capita; share of renewable energy sources; percentage of European financing allocated for lowcarbon development, etc.);

3. National goals set in parallel with the pan-European ones (reduction of GHG emissions by 2030; reduction of GHG emissions by 2050; share of renewable energy sources by 2030; goals for abandoning coal-fired electricity generation);

4. Countries' efforts to develop climate and energy legislation

5. The level of support for the EU's most ambitious climate and energy goals by 2030 and 2050 .

According to these criteria, European countries are divided into 5 categories - very high, high, moderate, low, and very low. At the moment, no country is included in the first, most ambitious group, and only in one country, in Sweden, the policy to reduce emissions is assessed at the level of high ambitiousness. Most European countries are characterized by low and very low levels of ambitiousness.

The main disadvantage of the European CAN assessment is the small sample of countries (27 EU countries and the UK), which does not allow to compare EU countries with other countries in the region as well as the European region with other regions of the world.

Another tool for monitoring countries' efforts to combat climate change is the Climate Change Performance Index, which covers 57 countries and the EU as a whole and allows to compare countries' ambitiousness and their progress in climate policy. The results of the rating are determined by the total efficiency of the country's activities on 14 indicators within four categories: GHG emissions (40\% of the total estimate), renewable energy sources (20\%), energy use (20\%), and climate policy (20\%).

The last category - Climate Policy Component - of the index includes two components: domestic and international. Data for climate policy assessment are collected in non-governmental institutions by filling out a questionnaire by independent experts containing estimates from 1 (weak policy) to 5 (strong policy) regarding the effect of measures taken by the Government of the country to reduce GHG emissions.

The "domestic" component evaluates the effectiveness of measures related to the development of renewable energy sources, increasing energy efficiency in various sectors (housing, transport, industry, etc.), and also considers measures to prevent deforestation. In addition, the rating evaluates the NDC and their achievement. 
Likewise, in the CCPI rating, so far, no country has achieved sufficiently good results in implementing an effective climate policy aimed at reducing GHG emissions.

Finally, another indirect indicator of the ambitiousness of climate policy may be the use of a carbon price (carbon tax or emissions trading system). Now, a carbon price has been introduced in more than 60 countries and regions of the world [30]. The growing popularity of carbon price is due to its high efficiency against other climate policy instruments. Its implementation directly affects the economic incentives of enterprises and can reduce the competitiveness of the most carbon-intensive industries. In this regard, the willingness of a country or region to implement a carbon price in one form or another demonstrates the loyalty of most business and government entities to the introduction of economic restrictions on carbon-intensive activities in the form of an additional fee for emissions, which can serve as an indirect indicator of a country's ambitiousness to reduce GHG emissions [31].

\section{Factor and cluster analysis: input data and results}

To compare the ambitiousness of climate policy across countries and assess differences in the factors that can influence climate policy, factor and cluster analyses were conducted. The sample included 55 countries (see Table 4) and was analyzed for 6 variables (Table 2).

Table 2 Variables included into the factor analysis and their alleged influence on climate policy

\begin{tabular}{|c|c|c|c|}
\hline Factor & Hypothesis & Variable & Source \\
\hline $\begin{array}{l}\text { Climate change } \\
\text { vulnerability }\end{array}$ & $\begin{array}{l}\text { Increased vulnerability leads to more } \\
\text { active climate policy }\end{array}$ & $\begin{array}{l}\text { Vulnerability score } \\
\qquad(0 ; 1)^{4}\end{array}$ & $\begin{array}{l}\text { University } \\
\text { of Notre } \\
\text { Dame }\end{array}$ \\
\hline $\begin{array}{c}\text { Economic } \\
\text { development }\end{array}$ & $\begin{array}{c}\text { Developed countries can afford more } \\
\text { costly policy on GHG emissions } \\
\text { reduction }\end{array}$ & $\begin{array}{l}\text { GDP per capita, } \\
2010 \text { USD }\end{array}$ & $\begin{array}{l}\text { World } \\
\text { Bank }\end{array}$ \\
\hline Local air pollution & $\begin{array}{l}\text { Local air pollution is often associated } \\
\text { with the operation of carbon-intensive } \\
\text { industries. Local pollution reduction } \\
\text { policy and climate policy can } \\
\text { complement each other }\end{array}$ & $\begin{array}{l}\text { PM2,5 } \\
\text { micrograms per } \\
\text { cubic meter }\end{array}$ & $\begin{array}{l}\text { World } \\
\text { Bank }\end{array}$ \\
\hline $\begin{array}{c}\text { Energy } \\
\text { dependency }\end{array}$ & $\begin{array}{c}\text { Policies to reduce dependence on } \\
\text { energy imports contribute to the } \\
\text { adoption of measures to reduce GHG } \\
\text { emissions }\end{array}$ & $\begin{array}{l}\text { The ratio of energy } \\
\text { production to the } \\
\text { amount of energy } \\
\text { consumed }\end{array}$ & IEA \\
\hline
\end{tabular}

\footnotetext{
${ }^{4}$ Data varies in the interval $[0,21 ; 0,54]$
} 


\begin{tabular}{|c|c|c|c|}
\hline $\begin{array}{c}\text { Export of fossil } \\
\text { fuels }\end{array}$ & $\begin{array}{c}\text { Dependence on the fossil fuel exports } \\
\text { leaves less room for an active policy } \\
\text { of GHG emissions reduction }\end{array}$ & $\begin{array}{c}\text { The ratio of net } \\
\text { exports to the } \\
\text { amount of energy } \\
\text { consumed }\end{array}$ & IEA \\
\hline $\begin{array}{c}\text { Trade } \\
\text { specialization }\end{array}$ & $\begin{array}{c}\text { The country's trade specialization in } \\
\text { more carbon-intensive products } \\
\text { reduces the incentives to reduce GHG } \\
\text { emissions }\end{array}$ & $\begin{array}{c}\text { Carbon intensity of } \\
\text { net exports (tones of } \\
\left.\mathrm{CO}_{2} / \mathrm{USD}\right)\end{array}$ & EORA \\
\hline
\end{tabular}

Source: compiled by authors

At a preliminary stage, factor analysis was performed in order to reduce the dimension of the cluster analysis. The methodology of factor analysis consisted in withdrawing several principal components based on the variables given, using a Varimax rotation which maximizes the cumulative explained variance, using Kaiser normalization.

According to the results of factor analysis (Table 3), the variables were combined into two principal components. The first one characterizes the level of socio-economic development, and the second one - the level of self-sufficiency in energy resources.

\section{The level of socio-economic development}

The first principal component with a negative sign consists of GDP per capita and the carbon intensity of net exports, and with a positive sign - the level of exposure to climate change and the level of local air pollution. In general, combining these variables into one principal component seems quite reasonable. A high level of economic development often contributes to protection from climate risks. In developed countries, as a rule, the main problems with local air pollution have been solved to a large extent. Finally, countries with a high level of development are relatively more specialized in high-tech production and export of services compared to developing countries, where the carbon intensity of exports is usually higher.

\section{Self-sufficiency in energy resources}

The second principal component with opposite signs included two indicators - selfsufficiency in energy resources and export of energy resources. They explain how selfsufficient a country is in meeting its own energy needs and how important the role of energy exports is relative to the volume of its own energy consumption.

Table 3. Rotated component matrix

\begin{tabular}{|l|l|l|}
\hline & Component 1 & Component 2 \\
\hline
\end{tabular}




\begin{tabular}{|l|c|c|}
\hline Climate change vulnerability & 0,800 & $-0,042$ \\
\hline Economic development & $-0,808$ & 0,177 \\
\hline Local air pollution & 0,833 & 0,034 \\
\hline Energy dependency & $-0,070$ & 0,994 \\
\hline Export of fossil fuels & $-0,056$ & $-0,994$ \\
\hline Carbon intensity of net exports & $-0,517$ & $-0,026$ \\
\hline
\end{tabular}

Source: authors' calculations

By conducting a cluster analysis using the Ward linkage method, we were able to form four clusters. Several countries in the sample were not included ${ }^{5}$. The main characteristics of these four clusters and examples of the countries included in them are listed below (Table 4).

1 cluster - Very wealthy and energy deficient (e.g. Austria, Germany, Denmark, Ireland)

The first cluster includes countries with a high level of GDP per capita (median for the cluster is $\$ 5,281$ ), a medium level of energy dependence (43.5\%) and a medium level of indicator for fossil fuels export (55\%).

These countries are also characterized by a very low level of carbon intensity of net exports (-61.5 tons per dollar), a relatively low level of venerability to climate change (0.27), and a very low level of air pollution (10 micrograms per cubic meter).

This cluster included the countries with the highest absolute and relative emission reduction targets $(-32 \%$ and $-49 \%$, respectively), the highest CAN rating $(42 \%)$, and the Climate Policy Component of the Climate Performance Index (67). 15 of the 15 countries in this cluster use a carbon price.

2 cluster - Wealthy and very energy deficient (e.g. Greece, Spain, Italy, Cyprus, Lithuania).

The second cluster included countries with an average level of GDP per capita $(\$ 2,318)$, a very high level of energy dependence $(71.67 \%)$ and an extremely low level of energy exports $(27 \%)$. 5 Countries not included in the clusters: Cameroon, India, Zambia - countries with very low levels of wealth and high vulnerability to
climate change. 
These countries are also characterized by a very low level of carbon intensity of net exports (-50.7 tons per dollar), as well as an average level of vulnerability to climate change (0.31) and an average level of air pollution (16 micrograms per cubic meter).

This cluster included countries with high absolute and relative emission reduction targets $(-21 \%$ and $-34 \%$, respectively), high CAN rating (35\%), and Climate Policy Component of Climate Performance Index (54). 16 of the 17 countries in this cluster use a carbon price.

3 cluster - Medium income and energy abundant (e.g. Azerbaijan, Russia, Indonesia, Kazakhstan).

The third cluster included countries with low GDP per capita $(\$ 11,298)$, very low energy dependence $(-110 \%)$ and very high energy exports $(204 \%)$.

These countries are also characterized by a very high level of carbon intensity of net exports (51.4 tons per dollar), as well as an average level of exposure to climate change (0.31) and an average level of air pollution (15 micrograms per cubic meter).

This cluster included countries with low absolute emission reduction targets (-12\%), low Climate Policy Component of the Climate Performance Index (39). Three of the six countries in this cluster use a carbon price.

Russia, due to its high energy supply and dependence on the export of hydrocarbons, is also included in this cluster.

4 cluster - Low income and energy secure (e.g. Botswana, Guatemala, Belarus, Uzbekistan).

The fourth cluster included countries with very low GDP per capita $(\$ 7,512)$, low energy dependence (22\%) and high energy exports (72\%).

These countries are also characterized by an average level of carbon intensity of net exports (10.6 tons per dollar), as well as a very high (relative to other countries) level of vulnerability to climate change (0.36) and a very high level of air pollution (20 micrograms per cubic meter).

This cluster includes countries with extremely low values of absolute emission reductions (de facto - increase in emissions to the target year, median for the cluster $+4 \%$ ), low CAN rating (26\%) and Climate Policy Component index of climate performance (34). Only 6 of the 14 countries in this cluster use a carbon price. 
Table 4. Cluster analysis outcomes

\begin{tabular}{|c|c|c|c|c|c|c|c|c|c|c|c|c|}
\hline Clusters & Countries & $\begin{array}{c}\text { Climate change } \\
\text { vulnerability, } \\
0-1\end{array}$ & $\begin{array}{c}\text { GDP per } \\
\text { capita, U.S. } \\
\text { dollars } \\
(2010)\end{array}$ & $\begin{array}{l}\text { Level of local } \\
\text { air pollution, } \\
\text { microgram } \\
\text { per cubic } \\
\text { meters }\end{array}$ & \begin{tabular}{|c|} 
Energy \\
dependency, \\
the ratio of \\
energy \\
production to \\
the amount of \\
energy \\
consumed, \% \\
\end{tabular} & $\begin{array}{c}\text { Export of fossil } \\
\text { fuels, the ratio } \\
\text { of net exports to } \\
\text { the amount of } \\
\text { energy } \\
\text { consumed, } \%\end{array}$ & $\begin{array}{l}\text { Carbon } \\
\text { intensity of } \\
\text { net exports, } \\
\text { tones } \\
\mathrm{CO}_{2} / U S D\end{array}$ & $\begin{array}{c}\text { Median of } \\
\text { absolute NDC } \\
2016 / 2030\end{array}$ & $\begin{array}{c}\text { Median of } \\
\text { relative NDC } \\
2016 / 2030\end{array}$ & $\begin{array}{l}\text { Median of } \\
\text { CAN } \\
\text { estimate }\end{array}$ & $\begin{array}{l}\text { CC } \\
\text { Performance } \\
\text { Index } \\
\text { (Climate } \\
\text { Policy } \\
\text { Component) }\end{array}$ & $\begin{array}{l}\text { Number of } \\
\text { countries with } \\
\text { carbon price }\end{array}$ \\
\hline $\begin{array}{l}\text { I. Very wealthy } \\
\text { and energy } \\
\text { deficient }\end{array}$ & $\begin{array}{c}\text { Austria, Denmark, Finland, } \\
\text { France, Germany, Iceland, } \\
\text { Ireland, Luxembourg, New } \\
\text { Zealand, Sweden, Switzerland, } \\
\text { the UK, the USA, the } \\
\text { Netherlands, Spain }\end{array}$ & $\begin{array}{l}\text { Very low } \\
(0.27)\end{array}$ & $\begin{array}{l}\text { Very high } \\
(51281)\end{array}$ & $\begin{array}{l}\text { Very low } \\
\text { (10) }\end{array}$ & $\begin{array}{c}\text { Medium } \\
(43,5)\end{array}$ & $\begin{array}{l}\text { Medium } \\
\quad(55)\end{array}$ & $\begin{array}{c}\text { Very low } \\
(-61,5)\end{array}$ & $-32 \%$ & $-49 \%$ & $42 \% 6$ & $67^{7}$ & 15 из 15 \\
\hline $\begin{array}{l}\text { II. Wealthy and } \\
\text { very energy } \\
\text { deficient }\end{array}$ & $\begin{array}{c}\text { Chile, Costa Rica, Croatia, } \\
\text { Hungary, Latvia, Poland, Rep. } \\
\text { Poland, Rep. of Korea, } \\
\text { Belgium, Cyprus, Greece, } \\
\text { Italy, Japan, Lithuania, } \\
\text { Malta, Portugal, Singapore, } \\
\text { Slovenia } \\
\end{array}$ & $\begin{array}{l}\text { Medium } \\
(0.31)\end{array}$ & $\begin{array}{l}\text { Medium } \\
(23381)\end{array}$ & $\begin{array}{l}\text { Medium } \\
\quad(16)\end{array}$ & $\begin{array}{l}\text { Very high } \\
\quad(71,7)\end{array}$ & $\begin{array}{l}\text { Very low } \\
\text { (27) }\end{array}$ & $\begin{array}{c}\text { Very low } \\
(-50,7)\end{array}$ & $-21 \%$ & $-34 \%^{8}$ & $35 \%{ }^{9}$ & $54^{10}$ & 16 из 17 \\
\hline $\begin{array}{c}\text { III. Medium } \\
\text { income and energy } \\
\text { abundant }\end{array}$ & $\begin{array}{c}\text { Azerbaijan, Kazakhstan, } \\
\text { Indonesia, Russia, Australia, } \\
\text { Canada }\end{array}$ & $\begin{array}{l}\text { Medium } \\
(0.31)\end{array}$ & $\begin{array}{c}\text { Low } \\
(11298)\end{array}$ & $\begin{array}{l}\text { Medium } \\
\quad(15)\end{array}$ & $\begin{array}{l}\text { Very low } \\
(-110)\end{array}$ & $\begin{array}{l}\text { Very high } \\
\text { (204) }\end{array}$ & $\begin{array}{l}\text { Very high } \\
\quad(51,4)\end{array}$ & $-12 \%$ & - & - & $39^{11}$ & 3 из 6 \\
\hline $\begin{array}{l}\text { IV. Low income } \\
\text { and energy secure }\end{array}$ & $\begin{array}{c}\text { Belarus, Dominican Republic, } \\
\text { Botswana, Guatemala, } \\
\text { Tajikistan, China, Albania, } \\
\text { Brazil, Bulgaria, Estonia, } \\
\text { Mexico, Romania, Ukraine, } \\
\text { Uzbekistan } \\
\end{array}$ & $\begin{array}{l}\text { Very high } \\
(0.36)\end{array}$ & $\begin{array}{l}\text { Very low } \\
(7512)\end{array}$ & $\begin{array}{l}\text { Very high } \\
\text { (20) }\end{array}$ & $\begin{array}{l}\text { Low } \\
(22)\end{array}$ & $\begin{array}{l}\text { High } \\
(72)\end{array}$ & $\begin{array}{l}\text { Medium } \\
(10,6)\end{array}$ & $+4 \%$ & - & $26 \%$ & $34^{12}$ & 6 из 14 \\
\hline
\end{tabular}

\section{Source: authors' calculations, CCPI, Climatewatch, Climate Action Network, The World Bank}

${ }^{6}$ Median for each country from the cluster except the USA and Iceland

${ }^{7}$ Median for each country from the cluster except Iceland

Median for each country from the cluster except Malta, Cyprus, Croatia, Republic of Korea

${ }^{9}$ Median for each country from the cluster except Costa Rica, Singapore, Japan, Chile, Republic of Korea

${ }^{10}$ Median for each country from the cluster except Costa Rica and Singapore

${ }^{11}$ Median for each country from the cluster except Azerbaijan

${ }^{12}$ Median for each country from the cluster except Dominican Republic, Botswana, Guatemala, Tajikistan, Albania, Uzbekistan 


\section{Conclusions and discussion}

The results of the cluster analysis show that the most ambitious emission reduction targets are generally set by developed countries. The countries of the first and second clusters have the highest median of absolute and relative emission reduction targets, CAN rating, and Climate Policy Component index of climate performance. Almost all countries in the first and second clusters use carbon pricing in a form of a carbon tax or emissions trading system.

In contrast, the least developed countries - countries in the fourth cluster - have rather modest ambitions for climate policy; only a few of them use carbon pricing. At the same time, it is the countries in the fourth cluster that have extremely high values of indicators of local air pollution and vulnerability to climate change, which is probably explained by high negative correlation of these indicators with the level of economic development.

For many poor countries addressing fundamental social challenges through industrialization (which usually involves high emissions of greenhouse gases and localized pollutants) is a higher priority than GHG emissions reduction. Furthermore, many of them consider economic growth and the inevitable increase in emissions to be the main opportunities for mitigating and adapting to climate change in the future.

The results also indicate that energy-abundant countries typically pursue less aggressive climate policies and set less ambitious emission reduction targets than energydeficient countries. These differences are evident when comparing countries in the third cluster and the first two clusters, which are characterized by a relatively high share of energy imports in energy consumption. In contrast, the third cluster countries are characterized by high energy resources and carbon-intensive products export, potentially reducing incentives for active climate policy.

Overall, the results of this study suggest that the level of economic development, but also the other factors, such as energy availability and trade specialization, determine readiness and ambition to reduce emissions. As a rule, the poorest and most vulnerable countries have the least ambitious reduction targets. At the same time, rich and energy-deficient countries are more likely to build active climate policies and set more ambitious emission reduction targets.

Russia belongs to the cluster of middle-income and energy-abundant countries, possessing significant energy resources and being highly dependent on exports of hydrocarbons and carbon-intensive products. Despite the active development of Russia's regulatory framework for climate policy in recent years, the formulated emission reduction targets 
(without regard to the natural capacity of forest ecosystems) are still relatively less ambitious than those of the first and second cluster countries. The country lacks a system of emissions regulation capable of creating economic incentives for their reduction at the level of individual industries and companies.

In addition, Russia encounters a number of sensitive socio-economic problems (including falling real incomes and increasing poverty) that require substantial financial outlays from the government. That makes it difficult to pursue a proactive policy to reduce emissions and requires a balancing of priorities between climate goals and development objectives. The ability to resolve this contradiction in the coming years will largely depend on the development of specific solutions to reduce emissions, accompanied by positive effects for economic development - diversification of the national economy, improvement of competitiveness of Russian products in foreign markets, attracting investment and creation of new jobs in lowcarbon sectors of the economy.

Despite the priority of building a balanced domestic climate policy, these efforts can be effectively complemented by external policy engagement.

The results of this work provide a new perspective on the principles of determining the climate responsibilities of different countries. The UN Framework Convention on Climate Change [32], adopted in 1992 and underlying the Paris Agreement, establishes the principle of common but differentiated responsibilities of the parties. According to it, the level of economic development of countries is indirectly taken into account when submitting emission reduction targets. In other words, the current approach to climate responsibility recognizes the difference in emission reduction capacities that exists between developed and developing countries. The developed countries have traditionally been willing to take on more ambitious emission reduction targets than the developing ones.

This paper suggests that evaluating and comparing the success and ambitiousness of different countries' climate policies must initially assume that the economic opportunities and opportunity costs of reducing emissions vary from country to country and depend not only on the level but also on the type of economic development of the countries. In particular, the opportunity cost of reducing emissions in an energy-importing country seeking to reduce import dependence is relatively lower than in a country that exports fossil fuels and carbonintensive products. Exported fossil fuels and carbon-intensive products are in turn consumed in energy-deficient countries, which is not considered in the perception of global climate responsibility. 
Given the different incentive systems for reducing greenhouse gas emissions in energyimporting and carbon-exporting countries, it is difficult to expect the latter to be as ambitious and proactive in terms of climate policy. Within the existing system of international climate institutions, there is a growing urgency for increased cooperation between the two groups of countries - emission exporters and emission importers - aimed at addressing their mutual interests and real opportunities to reduce emissions. The achievement of the goal of the Paris Agreement may be difficult without the development of new mechanisms for cooperation between these groups of countries.

Consideration of differences in the opportunity cost of emission reductions can form the basis of Russian climate diplomacy, including becoming a key link in RussianEuropean climate cooperation. The EU countries traditionally import Russian energy resources (natural gas and oil) and carbon-intensive products (metals, chemical products, cement, etc.). At the same time, the tightening of European carbon regulation (including growing prices for emissions under the European Emissions Trading System and plans to introduce a border carbon adjustment mechanism) creates direct risks for Russian exporters of energy resources and carbon-intensive products. Moreover, given the limited potential for reducing emissions within the EU (most low-cost emission reduction opportunities have already been depleted), their further reduction within the Union will become increasingly costly.

A compromise and mutually beneficial solution could be the creation of a new format of cooperation between Russia and Europe - the "Russian-European Green Deal". Several estimates indirectly and directly indicate that it is much cheaper to reduce emissions in Russia than in the EU $[33,34]$. Currently, Russia is actively working on the creation of mechanisms for accounting and regulation of greenhouse gas emissions. These mechanisms could be compatible with the emission trading system or the EU's carbon border regulation system. As a result, Russia will be able to implement low-carbon projects, including the participation of European capital, while European countries will have additional opportunities for cheap emission reductions, which would bring countries closer to the solution of the global climate change problem.

The development and implementation of this format of cooperation can create a global precedent for the integration of national systems of carbon regulation and lay the foundation for a global system of mutual recognition of emission reduction units. It seems barely possible to solve the problem of climate change without a framework, in which both developed (mainly net importers of emissions) and developing (mainly net exporters of emissions) countries, 
especially the BRICS countries with a great potential for cost-effective reduction of emissions, could participate equally. 


\section{References}

Baker L., Newell P., Phillips J. (2014) The Political Economy of Energy Transitions: The Case of South Africa. New Political Economy, vol. 19, issue 6, pp. 791-818. Available at: https://doi.org/10.1080/13563467.2013.849674.

Bättig M. B., Bernauer T. (2009) National Institutions and Global Public Goods: Are Democracies More Cooperative in Climate Change Policy? International Organization, vol. 63, pp. 281-308. Available at: https://doi.org/10.1017/S0020818309090092.

Böhringer C., Peterson S., Schneider J., Winkler M. (2020) Carbon Pricing After Paris: Overview of Results From EMF 36. Paper presented at the 23rd Annual Conference on Global Economic Analysis (Virtual). Available at: https://www.gtap.agecon.purdue.edu/resources/res_display.asp?RecordID=6067 (accessed 10 November 2021).

Brun A. (2016) Conference Diplomacy: The Making of the Paris Agreement. Politics and Governance, vol. 4, no 3, pp. 115-23. Available at: https://doi.org/10.17645/pag.v4i3.649.

Chepeliev M., Osorio-Rodarte I., van der Mensbrugghe D. (2021) Distributional Impacts of Carbon Pricing Policies Under the Paris Agreement: Inter and Intra-Regional Perspectives. Energy Economics, vol. 102. Available at: https://doi.org/10.1016/j.eneco.2021.105530.

Dolata-Kreutzkamp P. (2008) Canada-Germany-EU: Energy Security and Climate Change. International Journal, vol. 63, no 3, pp. 665-81. Available at: https://www.jstor.org/stable/40204404.

European Commission (EC) (n.d.). Climate Strategies \& Targets. Available at: https://ec.europa.eu/clima/policies/strategies_en (accessed 29 December 2020).

Grigoryev L., Makarov I., Sokolova A., Pavlyushina V., Stepanov I. (2020) Climate Change and Inequality: How to Solve These Problems Jointly? International Organisations Research Journal, vol. 15, no 1, pp. 7-30 (in English). Available at: doi.org/10.17323/1996-7845-202001-01.

Grossman G. M., Krueger A. B. (1995) Economic Growth and the Environment. The Quarterly Journal of Economics, vol. 110, issue 2, pp. 353-77. Available at: https://doi.org/10.2307/2118443.

Halsnæs K., Trærup S. (2009) Development and Climate Change: A Mainstreaming Approach for Assessing Economic, Social, and Environmental Impacts of Adaptation Measures. Environmental Management, vol. 43, pp. 765-78. Available at: https://doi.org/10.1007/s00267-009-9273-0.

Hassan H. R., Cliff V. (2019) For Small Island Nations, Climate Change Is Not a Threat. It's Already Here. World Economic Forum, 24 September. Available at: https://www.weforum.org/agenda/2019/09/island-nations-maldives-climate-change/ (accessed 29 December 2020).

Heggelund G. (2007) China's Climate Change Policy: Domestic and International Developments. Asian Perspective, vol. 31, no 2, pp. 155-91. Available at: https://www.jstor.org/stable/42704593.

Höhne N., Kuramochi T., Warnecke C., Röser F., Fekete H., Hagemann M., Day T., Tewari R., Kurdziel M., Sterl S., Gonzales S. (2017) The Paris Agreement: Resolving the Inconsistency Between Global Goals and National Contributions. Climate Policy, vol. 17, issue 1, pp. 16-32. Available at: https://doi.org/10.1080/14693062.2016.1218320. 
Ide T. (2020) Recession and Fossil Fuel Dependence Undermine Climate Policy Commitments. Environmental Research Communications, vol. 2, no 10 . Available at: https://doi.org/10.1088/2515-7620/abbb27.

Intergovernmental Panel on Climate Change (IPCC) (2018) Summary for Policymakers. Global Warming of $1.5^{\circ} \mathrm{C}$. An IPCC Special Report on the Impacts of Global Warming of $1.5^{\circ} \mathrm{C}$ Above Pre-Industrial Levels and Related Global Greenhouse Gas Emission Pathways, in the Context of Strengthening the Global Response to the Threat of Climate Change, Sustainable Development, and Efforts to Eradicate Poverty (V. Masson-Delmotte, P. Zhai, H.-O. Pörtner, D. Roberts, J. Skea, P. R. Shukla, A. Pirani, W. Moufouma-Okia, C. Péan, R. Pidcock, S. Connors, J. B. R. Matthews, Y. Chen, X. Zhou, M. I. Gomis, E. Lonnoy, T. Maycock, M. Tignor, T. Waterfield (eds)). Available at: https://www.ipcc.ch/site/assets/uploads/sites/2/2019/05/SR15_SPM_version_report_LR.pdf (accessed 29 December 2020).

Kaika D., Zervas E. (2013a) The Environmental Kuznets Curve (EKC) Theory. Part A: Concept, Causes and the $\mathrm{CO}_{2}$ Emissions Case. Energy Policy, vol. 62, pp. 1392-402. Available at: https://doi.org/10.1016/j.enpol.2013.07.131.

Kaika D., Zervas E. (2013b) The Environmental Kuznets Curve (EKC) Theory. Part B: Critical Issues. Energy Policy, vol. 62, pp. 1403-11. Available at: https://doi.org/10.1016/j.enpol.2013.07.130.

Levy D., Egan D. (2003) A Neo-Gramscian Approach to Corporate Political Strategy: Conflict and Accommodation in the Climate Change Negotiations. Journal of Management Studies, vol. 40, no 4, pp. 803-29. Available at: https://doi.org/10.1111/1467-6486.00361.

Makarov I. A. (2018) Discrepancies Between Environmental Kuznets Curves for Productionand Consumption-based $\mathrm{CO}_{2}$ Emissions. Higher School of Economics Research Paper No WP BRP 199/EC/2018. Available at: https://papers.ssrn.com/sol3/papers.cfm?abstract_id=3259100 (accessed 29 December 2020).

McMullen-Laird L., Zhao X., Gong M., McMullen S. J. (2015) Air Pollution Governance as a Driver of Recent Climate Policies in China. Carbon \& Climate Law Review, vol. 9, issue 3, pp. 243-55.

Meckling J., Wagner G., Sterner T. (2017) Policy Sequencing Toward Decarbonization. Nature Energy, vol. 2, no 12, pp. Available at: https://doi.org/10.1038/s41560-017-0025-8.

Mendelsohn R. (2009) The Impact of Climate Change on Agriculture in Developing Countries. Journal of Natural Resources Policy Research, vol. 1, issue 1, pp. 5-19. Available at: https://doi.org/10.1080/19390450802495882.

Mertz O., Halsnæs K., Olesen J. E., Rasmussen K. (2009) Adaptation to Climate Change in Developing Countries. Environmental Management, vol. 43, no 5, pp. 743-52 Available at: https://doi.org/10.1007/s00267-008-9259-3.

Off target. Ranking of EU countries' ambition and progress in fighting climate change (2018) // Climate Action Network. Available at: https://caneurope.org/content/uploads/2018/06/CAN_Off-target_report_FIN.pdf (accessed 10 October 2021).

Parry M. L., Canziani O. F., Palutikof J. P., van der Linden P., Hanson C. E. (eds) (2007) Climate Change 2007: Impacts, Adaptation, and Vulnerability. Cambridge: Cambridge University Press. 
Schmitz H. (2017) Who Drives Climate-Relevant Policies in the Rising Powers? New Political Economy, vol. 22, issue 5, pp. 521-40. Available at: https://doi.org/10.1080/13563467.2017.1257597.

Selden T. M., Song D. (1994) Environmental Quality and Development: Is There a Kuznets Curve for Air Pollution Emissions? Journal of Environmental Economics and Management, vol. 27, issue 2, pp. 147-62. Available at: https://doi.org/10.1006/JEEM.1994.1031.

Shafik N., Bandyopadhyay S. (1992) Economic Growth and Environmental Quality: TimeSeries and Cross-Country Evidence. Working Paper WPS 904, The World Bank. Available at: https://documents1.worldbank.org/curated/en/833431468739515725/pdf/multi-page.pdf (accessed 10 November 2021).

Stepanov I.A., Galimova K.Z. Carbon price: theory and practice of greenhouse gas emissions regulation. Moscow University Economics Bulletin. 2021;(4):95-116. (In Russ.) https://doi.org/10.38050/01300105202145

Stern D. I. (2017) The Environmental Kuznets Curve After 25 Years. Journal of Bioeconomics, vol. 19, no 1, pp. 7-28. Available at: https://doi.org/10.1007/s10818-017-9243-1.

Tørstad V., Sælen H., Bøyum L. S. (2020) The Domestic Politics of International Climate Commitments: Which Factors Explain Cross-Country Variation in NDC Ambition? Environmental Research Letter, vol. 15, no 2. Available at: https://doi.org/10.1088/17489326/ab63e0.

Uchiyama K. (2016) Environmental Kuznets Curve Hypothesis and Carbon Dioxide Emissions. Tokyo: Springer.

United Nations (UN) (1992) Ramochnaja konvencija Organizacii Ob'edinennyh Nacij ob izmenenii klimata [UN Framework Convention on Climate Change]. Available at: https://www.un.org/ru/documents/decl_conv/conventions/climate_framework_conv.shtml (accessed 11 November 2021) (in Russian).

van Alstine J., Neumayer E. (2010) The Environmental Kuznets Curve. Handbook on Trade and the Environment (K. P. Gallagher (ed)). Cheltenham, UK. pp. 49-59.

Woodward A., Baumgartner J., Ebi K. L., Gao J., Kinney P. L., Liu Q. (2019) Population Health Impacts of China's Climate Change Policies. Environmental Research, vol. 175, pp. 178-85. Available at: https://doi.org/10.1016/j.envres.2019.05.020.

World Bank Group (WBG) (2020) State and Trends of Carbon Pricing 2020. Available at: https://openknowledge.worldbank.org/bitstream/handle/10986/33809/9781464815867.pdf?se quence $=4 \&$ is Allowed $=y$ (accessed 10 November 2021). 


\section{Annex}

Table 5. Conversion of NDC in given countries into the compatible indicator of ambitiousness of climate policy

\begin{tabular}{|c|c|c|c|c|c|c|}
\hline $\begin{array}{c}\text { Country / } \\
\text { base year } \\
\text { NDC }\end{array}$ & $\begin{array}{c}\text { NDC reduction } \\
\text { by the target } \\
\text { year }(2030) \\
\text { compared to } \\
\text { the base } \\
\text { year, } \%\end{array}$ & Target type & $\begin{array}{c}\text { Emissions in } \\
\text { the base year, } \\
\text { million tons } \\
\text { of } \mathrm{CO}_{2} \text {-eq. }\end{array}$ & $\begin{array}{l}\text { Emissions in } \\
\text { 2016, million } \\
\text { tons of } \mathrm{CO}_{2-} \\
\text { eq. }\end{array}$ & $\begin{array}{c}\text { Compatibl } \\
\text { e target: } \\
\text { absolute } \\
\text { change by } \\
2030 \\
\text { compared } \\
\text { to } 2016, \%\end{array}$ & $\begin{array}{c}\text { Compatible } \\
\text { target: } \\
\text { change in } \\
\text { the carbon } \\
\text { intensity of } \\
\text { GDP by } \\
2030 \\
\text { compared } \\
\text { to } 2016, \%\end{array}$ \\
\hline $\begin{array}{c}\text { Australia / } \\
2005\end{array}$ & $26-28 \%$ & Absolute & 622,46 & 519,09 & $-11 \%$ & $-39 \%$ \\
\hline $\begin{array}{c}\text { Austria / } \\
2010\end{array}$ & $25 \%$ & Absolute & 78,38 & 71,85 & $-18 \%$ & $-35 \%$ \\
\hline $\begin{array}{c}\text { Azerbaijan / } \\
1990\end{array}$ & $35 \%$ & Absolute & 75,56 & 73,98 & $-34 \%$ & - \\
\hline $\begin{array}{c}\text { Albania / } \\
2016\end{array}$ & $12 \%$ & Absolute & 4,4 & 4,4 & $-12 \%$ & - \\
\hline Angola / 2005 & $35 \%$ & $\mathrm{BAU}$ & 191,8 & 180,12 & $-30 \%$ & - \\
\hline $\begin{array}{c}\text { Belarus / } \\
1990\end{array}$ & $28 \%$ & Absolute & 126,04 & 80,7 & $12 \%$ & - \\
\hline $\begin{array}{l}\text { Belgium / } \\
2010\end{array}$ & $31 \%$ & Absolute & 121,56 & 107,35 & $-22 \%$ & $-38 \%$ \\
\hline Brazil / 2005 & $43 \%$ & Absolute & 2015,48 & 1379,38 & $-17 \%$ & $-42 \%$ \\
\hline $\begin{array}{c}\text { Great Britain } \\
\text { / } 2010\end{array}$ & $30 \%$ & Absolute & 581,78 & 461,54 & $-12 \%$ & $-30 \%$ \\
\hline $\begin{array}{c}\text { Hungary / } \\
2010\end{array}$ & $12 \%$ & Absolute & 62,94 & 61,28 & $-10 \%$ & $-37 \%$ \\
\hline $\begin{array}{c}\text { Guatemala / } \\
2005\end{array}$ & $23 \%$ & BAU & 43,82 & 43,79 & $9 \%$ & - \\
\hline $\begin{array}{c}\text { Germany / } \\
2017\end{array}$ & $38 \%$ & Absolute & & 808,73 & $-38 \%$ & $-49 \%$ \\
\hline Greece / 2010 & $25 \%$ & Absolute & 107,44 & 86,36 & $-7 \%$ & $-29 \%$ \\
\hline $\begin{array}{c}\text { Denmark / } \\
2010\end{array}$ & $41 \%$ & Absolute & 62,23 & 46,66 & $-21 \%$ & $-39 \%$ \\
\hline $\begin{array}{c}\text { Dominican } \\
\text { Republic / } \\
\mathbf{2 0 1 0}\end{array}$ & $25 \%$ & Absolute & 24,28 & 28,9 & $-37 \%$ & - \\
\hline $\begin{array}{c}\text { Zambia / } \\
2010\end{array}$ & $47 \%$ & BAU & 459,88 & 493,99 & $-88 \%$ & - \\
\hline India / 2005 & $33-35 \%$ & Relative & 1803,32 & 3235,66 & $-64 \%$ & $-9 \%$ \\
\hline $\begin{array}{c}\text { Indonesia / } \\
2015\end{array}$ & $29 \%$ & BAU & - & 2229 & $-9 \%$ & $-51 \%$ \\
\hline $\begin{array}{c}\text { Ireland / } \\
2010\end{array}$ & $21 \%$ & Absolute & 58,34 & 65,58 & $-30 \%$ & $-54 \%$ \\
\hline $\begin{array}{l}\text { Iceland / } \\
2010\end{array}$ & $56 \%$ & Absolute & 3,18 & 3,19 & $-56 \%$ & $-69 \%$ \\
\hline Spain / 2010 & $22 \%$ & Absolute & 316,47 & 283,8 & $-13 \%$ & $-30 \%$ \\
\hline Italy / 2010 & $31 \%$ & Absolute & 437,79 & 369,63 & $-18 \%$ & $-27 \%$ \\
\hline $\begin{array}{c}\text { Kazakhstan / } \\
1990\end{array}$ & $25 \%$ & Absolute & 309,08 & 289,02 & $-20 \%$ & - \\
\hline
\end{tabular}




\begin{tabular}{|c|c|c|c|c|c|c|}
\hline $\begin{array}{c}\text { Cameroon / } \\
2010\end{array}$ & $32 \%$ & Absolute & 201,39 & 208,38 & $-34 \%$ & - \\
\hline $\begin{array}{c}\text { Canada / } \\
2005\end{array}$ & $30 \%$ & Absolute & 971,7 & 779,27 & $-13 \%$ & $-32 \%$ \\
\hline $\begin{array}{c}\text { Cyprus / } \\
2005\end{array}$ & $26 \%$ & Absolute & 8,84 & 8,26 & $-21 \%$ & - \\
\hline China / 2005 & $60 \%$ & Relative & 9280 & 11576,87 & $-20 \%$ & $-49 \%$ \\
\hline $\begin{array}{c}\text { Costa Rica / } \\
2012\end{array}$ & $25 \%$ & Absolute & 2,97 & 4,36 & $-49 \%$ & $-68 \%$ \\
\hline Latvia / 1990 & $40 \%$ & Absolute & 26,3 & 11 & $43 \%$ & $3 \%$ \\
\hline $\begin{array}{c}\text { Lithuania / } \\
2010\end{array}$ & $67 \%$ & Absolute & 19,28 & 17,71 & $-64 \%$ & $-72 \%$ \\
\hline $\begin{array}{c}\text { Luxembourg } \\
\text { / } 2010\end{array}$ & $30 \%$ & Absolute & 11,91 & 9,77 & $-15 \%$ & $-44 \%$ \\
\hline Malta / 2010 & $35 \%$ & Absolute & 3,01 & 1,92 & $2 \%$ & - \\
\hline $\begin{array}{c}\text { Mexico / } \\
2013\end{array}$ & $25 \%$ & BAU & - & 688,38 & $10 \%$ & $-24 \%$ \\
\hline $\begin{array}{c}\text { Netherlands / } \\
2010\end{array}$ & $37 \%$ & Absolute & 200,66 & 186,98 & $-32 \%$ & $-49 \%$ \\
\hline $\begin{array}{l}\text { New Zealand } \\
\text { / } 2005\end{array}$ & $30 \%$ & Absolute & 67,62 & 63,13 & $-25 \%$ & $-49 \%$ \\
\hline $\begin{array}{c}\text { Norway / } \\
2010\end{array}$ & $83 \%$ & Absolute & 26,53 & 23,81 & $-81 \%$ & $-85 \%$ \\
\hline Poland / 2010 & $26 \%$ & Absolute & 282,52 & 349,76 & $-40 \%$ & $-58 \%$ \\
\hline $\begin{array}{l}\text { Portugal / } \\
2010\end{array}$ & $15 \%$ & Absolute & 68,18 & 69,39 & $-16 \%$ & $-34 \%$ \\
\hline Russia / 1990 & $33 \%$ & Absolute & 3559,4 & 2391,38 & $0 \%$ & - \\
\hline $\begin{array}{l}\text { Romania / } \\
2010\end{array}$ & $11 \%$ & Absolute & 110,23 & 91 & $8 \%$ & - \\
\hline $\begin{array}{c}\text { Singapore / } \\
2005\end{array}$ & $36 \%$ & Relative & 50,8 & 63,25 & $-26 \%$ & $27 \%$ \\
\hline $\begin{array}{l}\text { Slovenia / } \\
2010\end{array}$ & $63 \%$ & Absolute & 11,26 & 10,99 & $-62 \%$ & $-70 \%$ \\
\hline $\begin{array}{l}\text { The USA / } \\
2005\end{array}$ & $26-28 \%$ & Absolute & 6477,6 & 5833,49 & $-32 \%$ & $-48 \%$ \\
\hline $\begin{array}{c}\text { Tajikistan / } \\
1990\end{array}$ & $25-35 \%$ & Absolute & 11,09 & 5,35 & $55 \%$ & - \\
\hline $\begin{array}{c}\text { Uzbekistan / } \\
2010\end{array}$ & $10 \%$ & Relative & 215,04 & 194,67 & $14 \%$ & $49 \%$ \\
\hline $\begin{array}{l}\text { Ukraine } \\
/ 1990\end{array}$ & $40 \%$ & Absolute & 874,78 & 283,72 & $85 \%$ & - \\
\hline $\begin{array}{c}\text { Finland } \\
/ 1990\end{array}$ & $47 \%$ & Absolute & 54,75 & 63,16 & $-54 \%$ & $-63 \%$ \\
\hline France / 1990 & $85 \%$ & Absolute & 466,55 & 329,6 & $-79 \%$ & $-83 \%$ \\
\hline $\begin{array}{c}\text { Croatia / } \\
2010\end{array}$ & $5 \%$ & Absolute & 16,54 & 18,94 & $-17 \%$ & - \\
\hline Chile / 2010 & $26 \%$ & Relative & 70,2 & 87,9 & $-41 \%$ & $-13 \%$ \\
\hline $\begin{array}{c}\text { Switzerland / } \\
2005\end{array}$ & $51 \%$ & Absolute & 53,11 & 46,72 & $-44 \%$ & $-56 \%$ \\
\hline $\begin{array}{c}\text { Sweden / } \\
2010\end{array}$ & $58 \%$ & Absolute & 55,23 & 46,23 & $-50 \%$ & $-64 \%$ \\
\hline $\begin{array}{c}\text { Estonia / } \\
1990\end{array}$ & $70 \%$ & Absolute & 35,16 & 20,38 & $-48 \%$ & $-64 \%$ \\
\hline Korea / 2017 & $20 \%$ & BAU & - & 657,4 & $-18 \%$ & - \\
\hline Japan / 2013 & $26 \%$ & Absolute & 1335,18 & 1263,87 & $-22 \%$ & $-32 \%$ \\
\hline
\end{tabular}

Source: compiled by authors based on Climatewatch 